\title{
Spatial arrangement of the stages of the cycle of the seminiferous epithelium in the Japanese quail, Coturnix coturnix japonica
}

\author{
M. Lin and R. C. Jones \\ Department of Biological Sciences, University of Newcastle, New South Wales 2308, Australia
}

\begin{abstract}
Summary. The spatial arrangement of the stages of the cycle of the seminiferous epithelium of the Japanese quail was investigated by preparing three-dimensional reconstructions of a seminiferous tubule from each of 3 quails. It was found that the stages were not distributed at random, but were arranged in a wave which spiralled helically along a seminiferous tubule. Adjacent stages in space were always adjacent numbers in the cycle of the seminiferous epithelium. Complete spermatogenetic waves were found in which all 10 stages of the cycle were in sequential order. However, in most waves the sequential order of stages was disturbed by the occurrence of modulations. The area of a cellular association varied from 4600 to $41600 \mu \mathrm{m}^{2}$ with a mean \pm s.e.m. ( 3 animals) of $17902 \pm 2614 \mu \mathrm{m}^{2}$. The number of Sertoli cells involved in an association ranged from 4 to 35 , with a mean \pm s.e.m. ( 3 animals) of $13 \cdot 5 \pm 2 \cdot 8$.

The findings support our earlier suggestion that the kinetics of spermatogenesis in the quail are fundamentally similar to the pattern which has been described for mammals.
\end{abstract}

Keywords: spermatogenesis; cellular associations; Japanese quail

\section{Introduction}

Although there is general agreement about the cycle and wave of spermatogenesis in mammals (Roosen-Runge, 1962; Clermont, 1972; Setchell, 1978), there has been some disagreement about these processes in birds (Clermont, 1958; Yamamoto et al., 1967; Aire et al., 1980). The main problem in studying the bird is that each cellular association of the seminiferous epithelium occupies only a small area of the seminiferous tubule and so it is difficult to determine the composition of the associations and, consequently, the cycle of the epithelium and the spatial arrangement of the stages of the cycle in the seminiferous tubule.

We initiated studies on the kinetics of spermatogenesis in the Japanese quail in order to resolve the nature of the process in this species in which there was contention about the composition of the cellular associations. Lin et al. (1990) described a preparatory method of fixation, which separated adjacent cellular associations so that their composition could be identified with confidence, and the use of $1-2 \mu \mathrm{m}$ thick epoxy sections to resolve cytological detail of the developing spermatids. Subsequently, a regular well defined spermatogenic cycle was confirmed using sections prepared without separating the cellular associations before fixation. Ten cellular associations of the seminiferous epithelium were identified. These stages of the spermatogenic cycle were classified according to the developmental state of the acrosome of spermatids (Leblond \& Clermont, 1952) and the nuclear morphology of spermatids (Roosen-Runge \& Giesel, 1950; Ortavant, 1954); the duration of a cycle was determined using radiolabelling techniques.

The study described in this report investigated the spatial arrangement of the stages of the cycle of the seminiferous epithelium in the quail. The study involved preparing serial sections of single 
seminiferous tubules and three-dimensional reconstructions of the tubules showing the distribution of the 10 stages of the cycle along the tubules.

\section{Materials and Methods}

Testes were obtained from 3 adult Japanese quails aged over 48 days. Single seminiferous tubules were separated from the testicular parenchyma by using a hypodermic syringe mounted with a 23 -gauge needle to flush the testes with $1 \%$ (v/v) glutaraldehyde in $0.1 \mathrm{M}$ phosphate buffer $(\mathrm{pH} 7.2)$. Lengths of about $3 \mathrm{~mm}$ of a seminiferous tubule were cut from the anastomosing network of tubules, transferred into $3 \%(\mathrm{v} / \mathrm{v})$ glutaraldehyde in phosphate buffer and fixed overnight (Lin et al., 1990). They were post-fixed in 1\% osmium tetroxide for $2 \mathrm{~h}$ and embedded separately in Spurr's resin (Agar Scientific Ltd, Stansted, Essex, UK). One tubule from each animal was selected for serial sectioning. Cross-sections 1.5 or $2.5 \mu \mathrm{m}$ thick were cut with glass knives on an ultracut $\mathrm{E}$ ultramicrotome (Reichert-Jung, Hernalser Hauptstr, Wien, Austria). The sections were stained in a solution of $1 \%(\mathrm{w} / \mathrm{v})$ toluidine blue and $0.5 \%(\mathrm{w} / \mathrm{v})$ borax in $30 \%(\mathrm{v} / \mathrm{v})$ ethanol.

Serial sections of the straight portions of three tubules were prepared ( 384 sections from a length of $960 \mu \mathrm{m}$ for Quail 208, 240 sections from a length of $600 \mu \mathrm{m}$ for Quail 269 and 480 sections from a length of $720 \mu \mathrm{m}$ for Quail 278). Photomicrographs were prepared (negative magnification $=\times 175$, print magnification $=\times 4$ ) of every 2 nd or 3rd section (a total of 390 photographs). All of the sections were examined under the light microscope to identify and label the stages of the cycle on each photograph according to the classification described in our previous study (Lin et al., 1990).

A right-angled Cartesian co-ordinate system (Schulze et al., 1986) was used to determine the location of each spermatogenic stage on the wall of a seminiferous tubule. The geometrical centre of a tubule was taken as the origin of the horizontal ( $\mathrm{x}$ ), vertical (Y) and longitudinal $(\mathrm{z})$ axes. The location of each stage of the cycle was determined by the angle which was made between the $\mathrm{x}$-axis and a line through the stage and the origin. The $z$-co-ordinates were determined from the knowledge that each section was 1.5 or $2.5 \mu \mathrm{m}$ thick. To reconstruct threedimensional scaled plans of the seminiferous tubules, the locations of all spermatogenic stages which were recorded on the photomicrographs were drawn on graph paper wrapped around a cylinder with a diameter of $100 \mathrm{~mm}$.

The area of the wall of a seminiferous tubule which was occupied by each cellular association was measured from the three-dimensional plan using an area meter Delta-T Device (Burwell, Cambridge, UK). The area of the wall of a tubule which was occupied by a Sertoli cell was calculated as a square; the side of the square was determined by measuring the distance between nuclei of adjacent Sertoli cells. The number of Sertoli cells involved in a cellular association was estimated from the area of an association divided by the area of a Sertoli cell.

\section{Results}

Only the 10 cellular associations described by Lin et al. (1990) were found in the seminiferous epithelium. The boundaries of most associations were recognized in serial sections even though there was some intermingling of germ cells from adjacent associations. Figure 1 shows that each association occupied a small area and so up to 12 associations could be identified in one crosssection of a seminiferous tubule. However, some of these associations were the same stage of the spermatogenic cycle separated by different stages.

\section{Arrangement of the spermatogenic stages}

Figure 2 shows that the stages were not distributed at random on the wall of a seminiferous tubule. A helical arrangement of the stages along the tubule was identified in which any two adjacent cellular associations were always adjacent stages in the cycle of the seminiferous epithelium. For example, any association in Stage II was always preceded or followed by either a Stage I or a Stage III association.

Figure 2 also shows, for each animal, the occurrence of a complete spermatogenetic wave in which the 10 stages of the cycle are arranged consecutively in the helical plan. However, modulations of the wave were commonly found, the order of the stages being frequently reversed for a certain length, and then reverting back to the original order. 


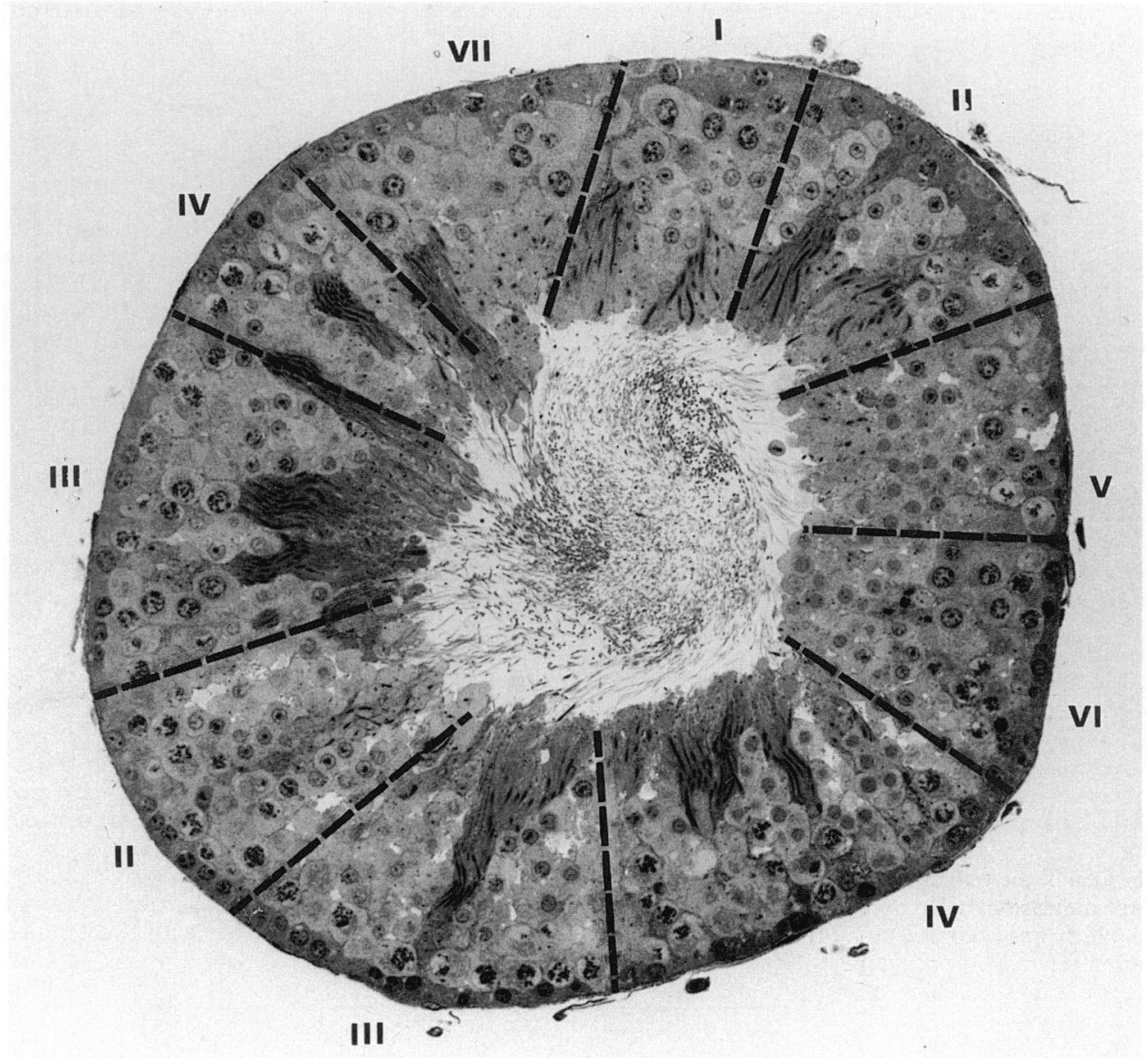

Fig. 1. A cross-section of an isolated seminiferous tubule of the quail showing the different stages of the cycle present. Embedded in Spurr's resin and stained with toluidine blue. I-VII, Stage I to Stage VII. $\times 940$.

\section{Magnitude of the cellular associations}

Figures 2(b) and (d) show that there was a problem in determining the boundaries of some cellular associations. This occurred when the same stage of the cycle was present in adjacent associations which were displaced by one helical turn around the tubule. Suggested boundaries of each association are indicated in Fig. 2 by dotted lines, but because of the uncertainty of their location the relevant associations were not-used to calculate the areas of cellular associations.

Table 1 shows estimates of the area of the wall of each seminiferous tubule which was covered by a cellular association. The areas varied from 4600 to $41600 \mu \mathrm{m}^{2}$ with a mean \pm s.e.m. for the 3 animals of $17902 \pm 2614 \mu \mathrm{m}^{2}$. There was no statistically significant difference in mean area of the different stages of the cycle.

Table 1 also shows the area of the wall of the tubule occupied by a Sertoli cell, and the number of Sertoli cells per cellular association. The area occupied by a Sertoli cell ranged from 888 to $2877 \mu \mathrm{m}^{2}$. The number of Sertoli cells in one cellular association ranged from 4 to 35 . 


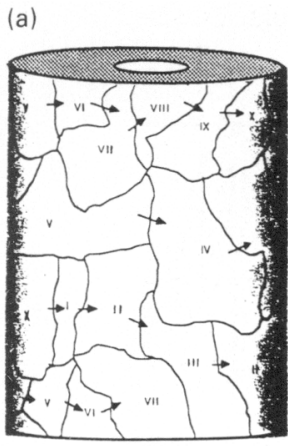

(c)

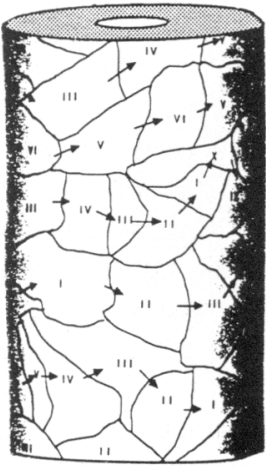

(e)

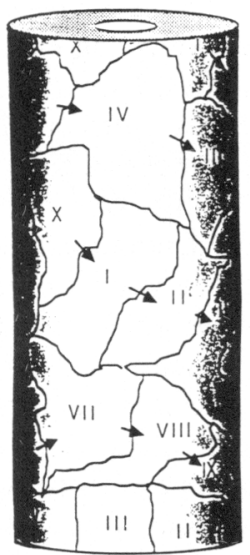

(b)

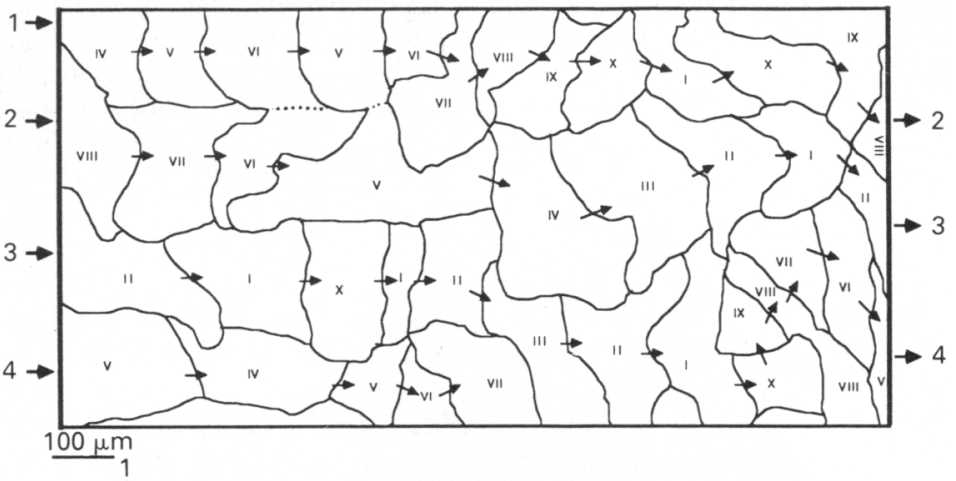

(d)

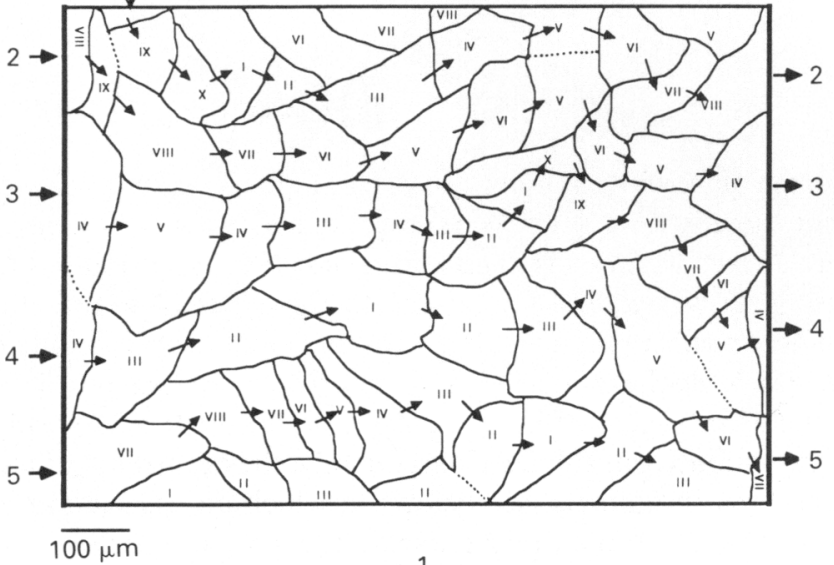

(f)

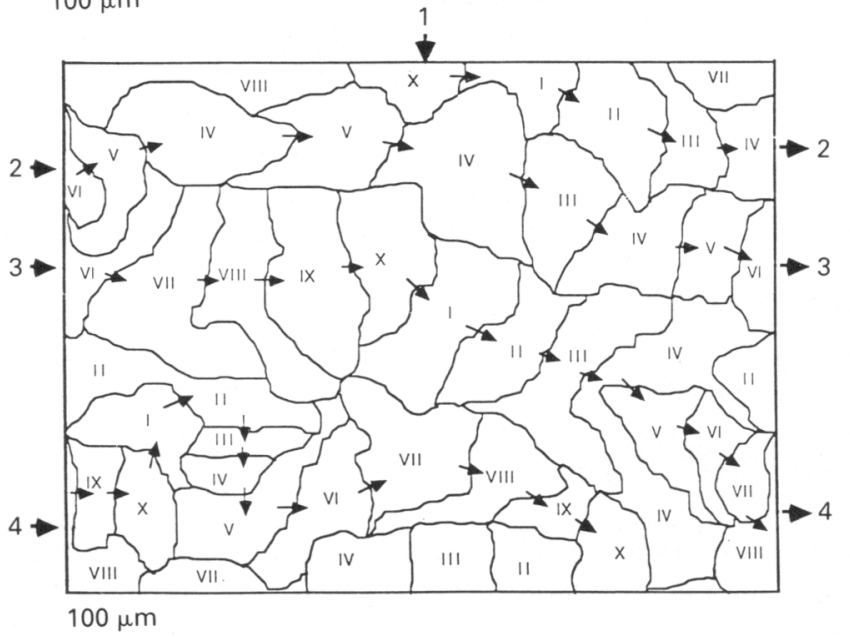

Fig. 2. Arrangement of the stages of the seminiferous epithelium along seminiferous tubules from Quails 269 (a, b), 208 (c, d) and 278 (e,f). Diagram (a), (c) and (e) show the arrangement in situ and (b), (d) and (f) are respectively (a), (c) and (e) unwrapped to show the arrangement of stages all around the tubules. Arrows indicate the proposed sequence of stages in a spermatogenic wave. The numbers at the sides of (b), (d) and (f) indicate the relationship of consecutive stages where the right and left sides of the diagrams join. Dotted lines indicate proposed boundaries where the one stage is made up of two components, one a turn of the helix above or below the other. 
Table 1. Area of the wall of a seminiferous tubule occupied by a cellular association of the seminiferous epithelium and by a Sertoli cell, and the number of Sertoli cells in a cellular association

\begin{tabular}{|c|c|c|c|c|c|}
\hline \multirow[b]{2}{*}{ Quail } & \multicolumn{2}{|c|}{ Cellular associations } & \multicolumn{3}{|c|}{ Sertoli cells } \\
\hline & $\begin{array}{c}\text { No. } \\
\text { measured }\end{array}$ & Area $\left(\mu \mathrm{m}^{2}\right)$ & $\begin{array}{c}\text { No. } \\
\text { measured }\end{array}$ & Area $\left(\mu \mathrm{m}^{2}\right)$ & $\begin{array}{l}\text { No. per } \\
\text { association }\end{array}$ \\
\hline $208^{2}$ & 37 & $12760 \pm 978$ & 23 & $1625 \pm 732$ & $7.9 \pm 1.9$ \\
\hline $269^{a}$ & 24 & $21291 \pm 1812$ & 21 & $1405 \pm 455$ & $15 \cdot 2 \pm 4 \cdot 1$ \\
\hline $278^{a}$ & 31 & $19655 \pm 1737$ & 24 & $1133 \pm 88$ & $17 \cdot 3 \pm 2.9$ \\
\hline Mean $^{b}$ & - & $17902 \pm 2614$ & - & $1388 \pm 142$ & $13 \cdot 5 \pm 2 \cdot 8$ \\
\hline
\end{tabular}

Values are mean \pm s.e.m. for 3 birds, with the s.e.m. calculated from the variance between ${ }^{a}$ stages within a seminiferous tubule and ${ }^{b}$ animals.

\section{Discussion}

The work on the quail which is described in this report is, with qualifications, in agreement with the proposal that there is a wave of spermatogenesis along a seminiferous tubule. The proposal has been attributed to von Ebner (1871) and Regaud (1901) and refers to the consecutive arrangement of the stages of the cycle at any one time along the length of a seminiferous tubule, and it has been supported with qualifications by studies on the rat and other mammals which have been studied (Perey et al., 1961; Hochereau, 1963; Courot et al., 1970; Amann, 1981). However, most workers studied mammals in which a cellular association may extend around and for a number of millimetres along a seminiferous tubule. Consequently, the occurrence of a spermatogenic wave is much more obvious than in animals (see below) in which an association covers such a small area of the tubule wall that more than one association is present in any cross-section of the tubule. This histological characteristic makes it difficult not only to identify the spermatogenic cycle of the seminiferous epithelium, but also to recognize the wave of spermatogenesis. The occurrence of a spermatogenic wave in these species was suggested by work on man and the crab-eating macaque (see Hilscher, 1983; Schulze, 1982; Schulze \& Rehder, 1984; Schulze et al., 1986; Dietrich et al., 1986). The arrangement of successive stages of development of primary spermatocytes in human seminiferous tubules and of spermatids in the macaque was reconstructed, and showed that the successive stages of development are arranged in a helical plan along the tubule. Our work on the quail differs from that on primates in that we have demonstrated the helical arrangement of the stages of the cycle of the seminiferous epithelium. It is considered significant that a spermatogenetic wave along the seminiferous tubule has been demonstrated in all of the species which have been studied intensively as it provides circumstantial evidence that the Sertoli cells which are controlling the activities of one cellular association may affect the activities of Sertoli cells in adjacent associations.

The main qualification which has been applied to the proposal that there is a wave of spermatogenesis along a seminiferous tubule is also applicable to the quail. The qualification was introduced by Perey et al. (1961) who noted that there are commonly modulations of the wave involving reversal of the order of the successive stages. They found that up to $80 \%$ of waves in the rat had modulations while $17 \%$ of the waves had more than 3 modulations. The occurrence of frequent modulations in the spermatogenic waves of the bull (Hochereau, 1963) and the crab-eating macaque (Dietrich et al., 1986) has also been reported.

Since there are considerably more anastomoses between seminiferous tubules in birds (Bailey, 1953; Lake, 1957; Marvan, 1969; Lin et al., 1990) than in mammals, it is impossible to prepare a single isolated seminiferous tubule from the quail in order to study the distribution of cellular associations along its length as has been done in mammals (Perey et al., 1961; Hochereau, 1963). 
Consequently, our study was limited to short lengths of tubule and it is not possible to make conclusions about the effect of the anastomoses on the waves, and the occurrence of reversal of waves at the meeting point of waves originating at opposite ends of a tubule.

Regaud's (1901) proposal, that there is a wave of spermatogenesis in space along a seminiferous tubule as there is in time at one location in the tubule, was not supported by subsequent work on the rat or the bull (Perey et al., 1961; Hochereau, 1963), and is not supported by this report on the quail.

Work on mammals indicates that the occurrence of more than one cellular association per cross-section of a seminiferous tubule occurs in at least some primates (Clermont, 1963; Chowdhury \& Marshall, 1980; Johnson et al., 1981; Dietrich et al., 1986) and the prototherian mammals (Benda, 1906). However, work on birds indicates that this is a feature of all species which have been studied (drake: Clermont, 1958; quail: Yamamoto et al., 1967; Lin et al., 1990; guinea fowl: Aire et al., 1980; domestic fowl: A. W. Blackshaw, personal communication). The occurrence of up to 12 cellular associations in a cross-section of a seminiferous tubule of the quail indicates that the area covered by a cellular association in the quail is very small. The estimate in this report shows that only $13.5 \pm 2.8$ Sertoli cells are involved in a cellular association in the quail. It is not known what determines the synchronization of Sertoli cells and the role of the synchronization in the dynamics of spermatogenesis. However, it is suggested that the synchronization may reflect differences in the nature of the paracrine regulation between the Sertoli cells and the intertubular cells and so it would be of interest to determine whether the same relationship exists between the stage of spermatogenesis and the size of the adjacent Leydig cells as has been described in the rat (Aoki \& Fawcett, 1978), and how the structure of the intertubular tissue compares to the 3 types described by Fawcett (1973).

It is concluded that the present results provide more evidence to support our suggestion (Lin et al., 1990) that the kinetics of spermatogenesis in the quail are similar to the pattern in mammals, especially primates. Our earlier report demonstrated that it is possible to identify cellular associations in the seminiferous tubules of the quail and arrange the associations into stages of the cycle of the seminiferous epithelium as described for mammals. This report demonstrates that the spatial arrangement of the stages is, as has been identified in mammals, in consecutive order of the stage number except for some modulations. The arrangement of the stages resembles that of primates more than other mammals because of the small area occupied by each cellular association, and because the spermatogenic wave is arranged in a helical plan along the seminiferous tubule.

\section{References}

Aire, T.A., Olowo-okorun, M.O. \& Ayeni, J.S. (1980) The seminiferous epithelium in the guinea fowl Numida meleagris. Cell Tiss. Res. 205, 319-325.

Amann, R.P. (1981) Spermatogenesis in the stallion: a review. J. equine Vet. Sci. July/August 1981, 131-139.

Aoki, A. \& Fawcett, D.W. (1978) Is there a local feedback from the seminiferous tubules affecting activity of the Leydig cells? Biol. Reprod. 19, 144-158.

Bailey, R.E. (1953) Accessory reproductive organs of maie fringillid birds: seasonal variations and response to various sex hormones. Anat. Rec. 115, 1-20.

Benda, C. (1906) Die Spermiogenese der Monotremen. Denkschriften Med.-Natur. Ges, 6, 413-438.

Chowdhury, A.K. \& Marshall, G. (1980) Irregular pattern of spermatogenesis in the baboon (Papio anubis) and its possible mechanism. In Testicular Development, Structure and Function, pp. 129-137. Eds A. Steinberger \& E. Steinberger, Raven Press, New York.

Clermont, Y. (1958) Structure de l'épithélium séminal et mode de renouvellement des spermatogonies chez le canard. Archs Anat. microsc. Morph. 47, 47-66.

Clermont, Y. (1963) The cycle of seminiferous epithelium in man. Am. J. Anat. 112, 35-52.

Clermont, Y. (1972) Kinetics of spermatogenesis in mammals: seminiferous epithelium cycle and spermatogonial renewal. Physiol. Rev. 52, 198-236.

Courot, M., Hochereau-de-Reviers, M.T. \& Ortavant, R. (1970) Spermatogenesis. In The Testis, vol. 1, pp. 339-432. Eds A. D. Johnson, W. R. Gomes \& N. L. VanDemark. Academic Press, New York.

Dietrich, T., Schulze, W. \& Riemer, M. (1986) Untersuchung zur Gliederung des Keimepithels beim Javaneraffen Macaca cynomolgus mittels digitaler Bildverarbeitung. Urologe $[A]$ 25, 179-186.

Fawcett, D.W. (1973) Observations on the organization of the interstitial tissue of the testis and on the occluding cell junctions in the seminiferous epithelium. Adv. Biosci. 10, 83-99. 
Hilscher, W. (1983) Problems of the Keimbahn. Biblthca Anat. 24, 1-21.

Hochereau, M.T. (1963) Étude comparée de la bague spermatogénétique chez le taureau et chez le rat. Annls Biol. anim. Biochim. Biophys. 3, 5-20.

Johnson, L., Petty, C.S. \& Neaves, W.B. (1981) A new approach to quantification of spermatogenesis. Biol. Reprod. 25, 217-226.

Lake, P.E. (1957) The male reproductive tract of the fowl. J. Anat. 91, 116-129.

Leblond, C.P. \& Clermont, Y. (1952) Spermatogenesis of rat, mouse, hamster and guinea pig as revealed by the periodic acid-fuchsin sulfurous acid technique. $\mathrm{Am}$. J. Anat. 90, 167-215.

Lin, M., Jones, R.C. \& Blackshaw, A.W. (1990) The cycle of the seminiferous epithelium in the Japanese quail (Coturnix coturnix japonica) and estimation of its duration. J. Reprod. Fert. 88, 481-490.

Marvan, F. (1969) Postnatal development of the male genital tract of the Gallus domesticus. Anat. Anz. 124, $443-462$.

Ortavant, R. (1954) Étude des générations spermatogoniales chez le bélier. C. r. Séanc. Soc. Biol. 148, 1958-1961.

Perey, B., Clermont, Y. \& Leblond, C.P. (1961) The wave of the seminiferous epithelium in the rat. Am.J. Anat. 108, 47-77.

Regaud, C. (1901) Études sur la structure des tubes séminifères et sur la spermatogénèse chez les mammifères. Archs Anat. microsc. Morph. exp. 4, 101-155 \& 231-380.
Roosen-Runge, E.C. (1962) The process of spermatogenesis in mammals. Biol. Rev. 37, 343-337.

Roosen-Runge, E.C. \& Giesel, L.O. (1950) Quantitative studies on spermatogenesis in the albino rat. Am. J. Anat. 87, 1-23.

Schulze, W. (1982) Evidence of a wave of spermatogenesis in human testis. Andrologia 14, 200-207.

Schulze, W. \& Rehder, U. (1984) Organisation and morphogenesis of the human seminiferous epithelium. Cell Tiss. Res. 237, $395-407$.

Schulze, W., Riemer, M., Rehder, U. \& Höhne, K.H. (1986) Computer-aided three-dimensional reconstructions of the arrangement of primary spermatocytes in human seminiferous tubules. Cell Tiss. Res. 244, 1-8.

Setchell, B.P. (1978) Spermatogenesis. In The Mammalian Testis, pp. 181-218. Paul Elek, London.

von Ebner, V. (1871) Untersuchung über den Bau der Samenkanalchen und die Entwicklung der Spermatozoiden bei den Säugetieren und beim Menschem. Untersuch. Inst. Physiol. Histol. Graz. 2, 200-236. Quoted from Perey et al. (1961).

Yamamoto, S., Tamate, H. \& Itikawa, O. (1967) Morphological studies on the sexual maturation in the male Japanese quail (Coturnix coturnix japonica). 2. The germ cell types and cellular associations during spermatogenesis. Tohoku J. Agric. Res. 18, $27-37$

Received 14 December 1989 